\title{
Edukacja wielokulturowa na lekcjach języka obcego w klasach niższych. Propozycje praktycznych rozwiązań dla nauczycieli
}

Streszczenie: Artykuł dotyczy kwestii związanych z wprowadzaniem treści z zakresu edukacji wielokulturowej na lekcjach języka obcego w klasach niższych. Zostały w nim przedstawione praktyczne rozwiązania, dzięki którym nauczyciel może uatrakcyjnić zajęcia, zaciekawić uczniów, a tym samym zachęcić ich do aktywnego udziału. Pozwoli im to na poszerzenie swojej świadomości wielokulturowej, która we współczesnym, zróżnicowanym kulturowo świecie jest podstawą do fascynacji, akceptacji i tolerancji wobec innych kultur.

Słowa kluczowe: edukacja wielokulturowa, język obcy, edukacja wczesnoszkolna

\section{Wprowadzenie}

Celem opracowania jest ukazanie konieczności wprowadzania treści z zakresu wielokulturowości podczas lekcji języka obcego, a w szczególności zwrócenie uwagi na jego znaczenie w nauczaniu dzieci na poziomie edukacji wczesnoszkolnej. Pomocnymi elementami, które mają wesprzeć te działania, są wszelkiego typu zadania aktywizujące i środki dydaktyczne, które poprzez swój charakter mają na celu nie tylko uatrakcyjnić zajęcia, ale również rozbudzić w uczniu zainteresowanie i zaangażowanie w dany temat. W wielu dokumentach jest mowa o potrzebie wprowadzania edukacji wielokulturowej już na poziomie kształcenia zintegrowanego.

Z chwilą wstąpienia Polski do Unii Europejskiej w życie weszło wiele rozporządzeń Rady Europy. Jednym z nich jest Biała Księga Dialogu Międzykulturowego ${ }^{1}$, w której znajdują się kwestie związane ze sprawami międzykulturowości, ale również z szerzeniem dialogu między kulturami różnych krajów.

1 Council of Europe Ministers of Foreign Affairs: White paper on Intercultural Dialogue "Living Together As Equals in Dignity". Strasburg 2008, Council of Europe. 
Inne dokumenty, o których warto wspomnieć, to: Powszechna Deklaracja UNESCO o Różnorodności Kulturowej ${ }^{2}$ oraz FREPA (System Opisu Pluralistycznych Podejść do Języków i Kultur) ${ }^{3}$.

W polskim prawie oświatowym wszelkie programy nauczania, na każdym etapie edukacyjnym, oparte są na Podstawie Programowej ${ }^{4}$, która sformułowana jest przez Ministra Edukacji Narodowej. Również i w tym dokumencie można znaleźć zagadnienia związane ze świadomością wielokulturową ucznia na poziomie edukacji wczesnoszkolnej.

W pierwszej kolejności przytoczę argumenty, które potwierdzają tezę o potrzebie uświadamiania uczniów klas niższych na temat życia w wielokulturowym społeczeństwie oraz tolerancji wobec innych kultur. Następnie poruszę sprawę dotyczącą roli nauczyciela w kreowaniu świadomości wielokulturowej uczniów. Ostatni rozdział zawiera propozycje zadań i środków dydaktycznych, które mogą pomóc osobom prowadzącym zajęcia z języka obcego włączyć dzieci do aktywnego udziału podczas lekcji, na których mogą poszerzyć swoją wiedzę o innych kulturach oraz nauczyć się empatii wobec nich.

\section{Argumenty przemawiające za wprowadzaniem elementów wielokulturowych w nauczaniu języka obcego uczniów z klas niższych}

Zwracanie uwagi na zjawiska wielokulturowości na lekcjach języka obcego ma duże znacznie we wszechstronnym rozwoju dziecka na poziomie edukacji wczesnoszkolnej. Takie spotkania to „wszelkie przejawy kontaktu z odmienną

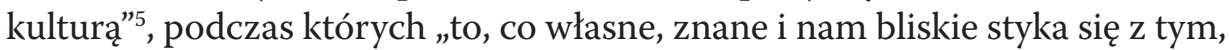
co dla nas nowe, inne, obce"6.

2 Polski Komitet ds. UNESCO: Powszechna deklaracja UNESCO o różnorodności kulturowej. http://www.unesco.pl/fileadmin/user_upload/pdf/Powszechna_Dekl_o_ roznorodnosci.pdf (8.01.2015).

3 M. Candelier: FREPA. A Framework of Reference for Pluralistic Approaches to Languages and Cultures. Competences and resources. http://www.ecml.at/tabid/277/ PublicationID/82/Default.aspx (8.01.2015).

4 Dziennik Ustaw z 2014r., Poz. 803: Podstawa Programowa Kształcenia Ogólnego Dla Szkót Podstawowych. http://bip.men.gov.pl/men_bip/akty_prawne/rozporzadzenie_20081223_zal_2.pdf (8.01.2015).

5 K. Mihułka: Spotkania interkulturowe z perspektywy uczenia się i nauczania języków obcych. "Języki obce w szkole” 2013, nr 2, s. 61.

6 Tamże, s. 60. 
Wprowadzenie treści wielokulturowych podczas edukacji glottodydaktycznej:

- dostarcza wiedzę o innych kulturach (tradycja, normy, wartości, zachowania ludzi itd.), co w konsekwencji rozszerza horyzonty myślowe ucznia,

- usprawnia świadomość istnienia różnic i podobieństw w kulturach oraz uczy wobec nich tolerancji, zrozumienia i szacunku,

- pomaga w zwalczaniu schematycznego myślenia, czyli stereotypów o innych kulturach,

- rozwija umiejętność obserwacji i analizy nowych zjawisk kulturowych, umiejętność dostrzegania związków przyczynowo-skutkowych, wiążących się ściśle z interakcjami z przedstawicielami innej kultury (np. empatia wobec nich sprawia, że są mile widziani w ich gronie, a jej brak prowadzi do izolacji w tym kręgu),

- pozwala na lepszy kontakt w spotkaniach wielokulturowych i wspiera rozwiązywanie nieporozumień wynikających z różnic kulturowych,

- rozwija zainteresowanie, chęć i motywację do poznawania „czegoś nowego”,

- buduje oraz rozwija indywidualną tożsamość kulturową ucznia,

- spełnia postulat konstruktywistyczny i wielokulturowe podejście mówiące o podnoszeniu motywacji do nauki przez odwoływanie się do własnych doświadczeń i emocji ucznia"7,

- kształci i rozwija następujące cechy: otwartość, komunikatywność, wrażliwość, tolerancję, serdeczność, empatię, spontaniczność, bezpośredniość w kontaktach z ludźmi o odmiennej kulturze, w których „nie widzą obcokrajowców”, a dzięki temu "mają mniejsze opory przed poznawaniem tego, co obce" 9

\section{Rola nauczyciela w kreowaniu świadomości wielokulturowej uczniów}

Rola nauczyciela jest niezwykle ważna w procesie nauczania języka obcego pod względem wielokulturowości. Ja sprowadzam ją do dwóch postaw: interpretatora zagadnień społeczno-kulturowych oraz motywatora.

7 H. Komorowska: Nauka języka obcego w perspektywie ucznia. Warszawa 2011, Oficyna Wydawnicza Łośgraf, s. 40.

8 M. Jałowiec-Sawicka: Pozytywny wpływ nauki języka obcego na rozwój dziecka. "Języki Obce w Szkole” 2006, nr 3, s. 18.

9 Tamże. 
Pierwsza z nich nawiązuje do ww. argumentów, którymi nauczyciel powinien się kierować w pracy z dziećmi. Odejście od zasady unikania języka ojczystego na zajęciach jest pierwszym warunkiem tej postawy. Bowiem w momentach, gdy zawarty w podręczniku materiał kulturowy wymaga odpowiedniego komentarza i wyjaśnienia, to nauczyciel powinien go wytłumaczyć za pomocą języka rodzimego. Dodatkowo, jeśli uczniowie sami chętnie zadają pytania i widać, że interesują się tematem, to zadaniem osoby prowadzącej zajęcia jest dodatkowe pogłębienie tej kwestii. Wówczas jej działanie będzie miało pozytywne skutki w kształtowaniu świadomości wielokulturowej ucznia.

Rola nauczyciela - motywatora, to kolejna umiejętność, którą osoba ucząca języka obcego powinna posiadać. Dzieci w młodszym wieku szkolnym potrzebują kogoś, kto dzięki swoim działaniom zachęci ich do odkrywania oraz rozumienia różnojęzyczności i różnorodności kulturowej. To sprawi, że polecone im zadanie zostanie przez nich wykonane rzetelnie, sumiennie, a przede wszystkich z chęcią i zapałem do osiągnięcia założonego celu. Aby motywacja była skuteczna, nauczyciel musi wykazać się kreatywnością w przygotowaniu i przeprowadzeniu lekcji, tak, aby ich ciekawość zawsze była na wysokim poziomie oraz aby uczniowie poznawali język obcy i wgłębili się w tajniki innej kultury. Nauczyciel powinien organizować zajęcia tak, by w jak najbardziej interesujący i efektywny sposób wprowadzić dziecko w świat wielokulturowości. Do tego będą potrzebne mu odpowiednie zadania aktywizujące i środki dydaktyczne.

\section{Zadania aktywizujące oraz środki dydaktyczne wspierające edukację wielokulturową na lekcjach języka obcego w klasach niższych}

J.-J. Guilbert pojęcie zadania rozumie jako „zaplanowane działanie, zgodne z założeniami i celami kształcenia, w wyniku, którego uczący się nabywa określoną wiedzę, umiejętności lub kształtuje swą osobowość" ${ }^{10}$. Zdobyte ww. elementy tworzą pewnego rodzaju ścieżkę, umożliwiającą opanowanie odpowiednich wzorców reagowania na własne i obce środowisko społeczno-kulturowe.

10 J.-J. Guilbert: Zarys pedagogiki medycznej. Warszawa 1983, Wydawnictwo Lekarskie PZWL, s. 607. 
Środki dydaktyczne są określane jako „pomost pomiędzy światem zjawisk a światem słów, pomost niezbędny szczególnie w pracy z dziećmi"11. Jak widać, w tym określeniu, pomoce dydaktyczne stanowią przejście z tego, co uczniowie mogą znaleźć na temat wielokulturowości w podręcznikach, do tego, co poprzez zastosowanie odpowiednich zadań mogą poznać głębiej na zajęciach w ciekawej i zabawowej formie.

Stosowanie wszelkiego rodzaju praktycznych rozwiązań wspierających edukację wielokulturową podczas nauczania języka obcego niesie ze sobą wiele zalet. Po pierwsze, nauczyciel może je wykorzystać podczas każdej lekcji języka obcego, wprowadzając jedynie niewielkie zmiany, biorąc pod uwagę np. wiek dzieci, liczbę uczestników, warunki w sali, zaangażowanie uczniów itd. Dodatkowym plusem jest to, że dzieci mają możliwość nie tylko poznania kultury przejawiającej się języku stanowiącym przedmiot nauczania, ale również zdobycia wiedzy o obyczajowości innych krajów. Tolerancja, szacunek, wrażliwość i akceptacja inności/odmienności to umiejętności, które uczeń, poprzez zadania z perspektywy kształtowania świadomości wielokulturowej, organizowanych przez nauczyciela na lekcji, jest w stanie wykształtować i rozwijać. Warto również wspomnieć, że uczniowie wzmacniają swoją tożsamość kulturową i przywiązanie oraz poszanowanie wobec niej. Ćwiczenia są okazją do wprowadzenia dzieci w świat innych kultur poprzez rozbudzenie ich naturalnej ciekawości poznawczej. Są one również świetną alternatywą do umożliwienia dzieciom analizy danego materiału w sposób atrakcyjny i zachęcający, co pozwala im na pracę, w której nie ma przymusu, czy stresu. Poprzez zabawę nauczyciel stwarza uczniom możliwość „pracy razem", robienia czegoś wspólnie i przeżywania pozytywnych emocji związanych z poznawaniem innych kultur. Dzięki temu, aktywność każdego ucznia jest „świetnym antidotum na sztywną atmosferę i blokady komunikacyjne uczestników, ponieważ wpływa pozytywnie na dynamikę grupy"12.

11 E. Skiba, A. Wieczorek: Program nauczania języka angielskiego dla klas I-III szkoty podstawowej, Warszawa 2009, Wydawnictwo Szkolne PWN, s. 29.

12 B. Rusek: Zabawy rozwijające sprawność mówienia w języku obcym. „Homo Ludens" 2010, nr 1, s. 152. 


\section{Propozycje zadań oraz środków dydaktycznych} wspierających rozwój świadomości międzykulturowej uczniów na zajęciach z języka obcego ${ }^{13}$

\section{Obrazek, plakat, rysunek, flashcards, zdjęcie, ilustracja itp.:}

a) Kolaż - cel: porównanie zachowań obyczajowych różnych społeczeństw czy grup kulturowych.

Tworzenie kolaży na zasadzie projektu edukacyjnego. Temat pracy: „Jak w ciekawy sposób zaprezentować, poprzez zebrane wiadomości i materiały, swoją i inną kulturę?". Uczniowie zostają podzieleni na grupy. Ich zadaniem jest stworzenie ciekawego, kolorowego kolażu z wcześniej zdobytych informacji i przyniesionych środków. Dodatkowo uczniowie (o ile potrafią i jest to dla nich możliwe) nadają tytuł kolażowi i podpisują poszczególne jego części w języku obcym. Mogą to być po prostu słowa kluczowe, np. „jedzenie”, „ubrania” itp. Po zakończonej pracy każda z grup prezentuje swoją pracę, a następnie wszyscy dokonują porównania przedstawionych treści.

b) Ubiór z różnych stron świata - cel: poznanie charakterystycznych strojów ludzi mieszkajacych w Afryce, na Grenlandii oraz w Europie, doskonalenie stownictwa z zakresu ubioru oraz kolorów.

Uczniowie zostają podzieleni na trzy grupy. Każda z nich otrzymuje po jednym zdjęciu (mieszkańca Afryki, Grenlandii i Europy). Zadaniem każdej z grup jest przygotowanie krótkiego opisu stroju danego przedstawiciela kultury. Uczniowie mają za zadanie zwrócić uwagę na rodzaj elementów stroju (kurtka, T-shirt itp.). Gdy grupy są gotowe, prezentują swoje opisy przed resztą klasy.

\section{Pacynka:}

a) jako pośrednik wielokulturowy - cel: poznanie zachowań, tradycji, zwyczajów charakterystycznych dla różnych kręgów kulturowych.

13 Przedstawiony przeze mnie zbiór kilku ćwiczeń oparty jest na propozycjach znajdujących się w następujących publikacjach: K. Mihułka: Sposoby rozwijania kompetencji interkulturowej na lekcji języka obcego. „Języki Obce w Szkole” 2012, nr 2, K. Marcinkowska, E. Miłoń, Zespół Akcji 1: Edukacja międzykulturowa. http://www. frse.org.pl/sites/frse.org.pl/files/publication/902/edukacja-pdf-25817.pdf (16.12.2014) oraz na podstawie własnych doświadczeń, praktyk oraz wolontariatu w Szkole Podstawowej im. Janusza Korczaka w Suszcu. 
Pacynka „może m.in. opowiadać o zwyczajach, omawiać odmienne formy zachowań i przybliżać dzieciom inną kulturę"14.

b) Podaj dalej - cel: powtórzenie nazw poznanych wcześniej państw Europy, odpowiednie dopasowanie flagi do danego kraju, poznanie ciekawej tradycji wywodzacej się z tego regionu.

Uczniowie, stojąc w kole, podają sobie pacynkę w rytm słyszanej melodii. Gdy ona ucichnie, dziecko trzymające pacynkę nakłada ją na rękę i wybiera jedną z pośród kilku leżących na dywanie flag oraz wymawia w języku obcym nazwę kraju, do którego ona należy. Nauczyciel dodatkowo wzbogaca zajęcia, przedstawiając dzieciom ciekawy zwyczaj, tradycję wywodzącą się z tego państwa. Zabawa toczy się dalej.

\section{Teksty, kartki z napisami itp.:}

a) Odrzucamy stereotypy - cel: kształtowanie umiejętności wyrażania własnych emocji, uczuć, rozwijanie postawy tolerancji wobec odmienności poprzez uświadomienie sobie konieczności odrzucenia stereotypowego myślenia.

Każda osoba otrzymuje od nauczyciela zdjęcie przedstawiciela danej kultury (np. afrykańskiej, amerykańskiej itd.) oraz pocięte kartki, na których znajdują się przykłady obyczajów oraz obrzędów, które mogą odnosić się do danej osoby na zdjęciu. To zadanie, „w którym uczniowie mają przypisać członkom różnych grup kulturowych cechy, ich zdaniem, charakterystyczne dla nich"15. Osoby mające te same zdjęcia dobierają się w grupy i tworzą wspólny obraz osoby na podstawie wymienionych przykładów zachowań, które pojawiły się najwięcej razy. Następuje prezentacja w języku obcym oraz dyskusja w języku ojczystym na temat zebranych informacji oraz własnych przemyśleń i dodatkowych wiadomości, które sami posiadają, a które odnoszą się do prezentowanej osoby.

\section{Pozostałe:}

a) Narodowe dania - cel: poznanie charakterystycznych składników, potraw z różnych miejsc świata, utrwalenie stownictwa z zakresu jedzenia.

To zadanie można wykonać z dziećmi np. podczas omawiania zwyczajów świątecznych w różnych krajach. Nauczyciel zwraca szczególną uwagę na po-

14 A. Jaroszewska: Gry i zabawy w nauczaniu języków obcych. W: A. Surdyk, J.Z. Szeja (red.): Kulturotwórcza funkcja gier. Gra w kontekście edukacyjnym, społecznym i medialnym. „Homo Communicativus” 2008, nr 2, s. 160.

15 K. Mihułka: Sposoby rozwijania kompetencji interkulturowej na lekcji jezzyka obcego. „Języki Obce w Szkole” 2012, nr 2, s. 112. 
trawy podawane w tym kraju podczas świąt np. Bożego Narodzenia (propozycja: ciasteczka Polvorones - Hiszpania). Przygotowanie z dziećmi potrzebnych składników na wypieki. Głośne wypowiadanie w języku obcym, poznanych na wcześniejszych lekcjach, nazw potrzebnych składników do ciasta i przyrządów do jego wykonania. Wyrobienie ciasta przez nauczyciela. Wykrawanie przez dzieci kółek. Po upieczeniu ciastek każdy uczeń może spróbować swojego wypieku.

\section{Podsumowanie}

Reasumując - umiejętności z zakresu języka obcego, wzbogacone treściami z edukacji wielo- i międzykulturowej, które dzieci będą zdobywać już od najmłodszych lat, z pewnością przyniosą znaczące rezultaty i efekty w ich przyszłym życiu. Świat, w którym żyjemy, a który stawia nam coraz wyższe wymagania, nie będzie dla dziecka czymś nieznanym, czymś, co może zahamować jego potrzebę rozwoju i kontaktu z osobami o odmiennej kulturze. Stanie się on dla dziecka „mniejszy” i „bezpieczniejszy”. Poprzez znajomość języka obcego i rozwiniętą świadomość wielokulturową będzie w stanie „poruszać się” w nim bez żadnych problemów i uprzedzeń. Dodatkowo będzie świadomy własnej tożsamości kulturowej oraz stanie się otwarty na poznawanie innych kultur i chętny do uczenia się tolerancji wobec życia i wobec przejawów wielokulturowości.

\section{Bibliografia}

Candelier M.: FREPA. A Framework of Reference for Pluralistic Approaches to Languages and Cultures. Competences and resources. http://www.ecml.at/ tabid/277/PublicationID/82/Default.aspx (8.01.2015). Graz 2012.

Council of Europe Ministers of Foreign Affairs: White paper on Intercultural Dialogue "Living Together As Equals in Dignity". Strasburg 2008, Council of Europe.

Dziennik Ustaw z 2014 r., poz. 803: Podstawa Programowa Kształcenia Ogólnego dla Szkót Podstawowych. http://bip.men.gov.pl/men_bip/akty_prawne/rozporzadzenie_20081223_zal_2.pdf (8.01.2015). bmw 2008.

Guilbert J.-J.: Zarys pedagogiki medycznej. Warszawa 1983, Wydawnictwo Lekarskie PZWL.

Jałowiec-Sawicka M.: Pozytywny wptyw nauki języka obcego na rozwój dziecka. „ęzyki Obce w Szkole”, 2006, nr 3. 
Jaroszewska A.: Gry i zabawy w nauczaniu języków obcych. W: A. Surdyk, J. Z. Szeja (red.): Kulturotwórcza funkcja gier. Gra w kontekście edukacyjnym, spotecznym i medialnym. „Homo Communicativus” 2008, nr 2.

Komorowska H.: Nauka języka obcego w perspektywie ucznia. Warszawa 2011, Oficyna Wydawnicza Lośgraf.

Marcinkowska K., Miłoń E., Zespół Akcji 1: Edukacja międzykulturowa. http://www.frse.org.pl/sites/frse.org.pl/files/publication/902/edukacja -pdf-25817.pdf (16.12.2014). Warszawa brw.

Mihułka K.: Sposoby rozwijania kompetencji interkulturowej na lekcji języka obcego. „Języki Obce w Szkole”, 2012, nr 2.

Mihułka K.: Spotkania interkulturowe z perspektywy uczenia się i nauczania języków obcych. „Języki Obce w Szkole” 2013, nr 2.

Polski Komitet ds. UNESCO: Powszechna deklaracja UNESCO o różnorodności kulturowej. http://www.unesco.pl/fileadmin/user_upload/pdf/Powszechna_Dekl_o_roznorodnosci.pdf (8.01.2015). bmirw.

Rusek B.: Zabawy rozwijajace sprawność mówienia w języku obcym. „Homo Ludens" 2010, nr 1.

Skiba E., Wieczorek A.: Program nauczania języka angielskiego dla klas I-III szkoty podstawowej, Warszawa 2009, Wydawnictwo Szkolne PWN.

\section{Rozszerzona literatura metodyczna mogąca mieć zastosowanie w nauczaniu języka obcego w klasach niższych szkoły podstawowej:}

Brzeziński J.: Nauczanie języków obcych dzieci. Wrszawa 1987, WSiP.

Brzozowska P.: Metoda Total Physical Response w praktyce szkolnej - przyktady ćwiczeń z języka angielskiego. „Języki obce w szkole” 2013.

Czwartos B.: Aktywność na lekcjach (języka obcego), czyli o zastosowaniu metod aktywizujacych. W: J. Knieja, S, Piotrkowski (red.): Nauczanie języka obcego a specyficzne potrzeby uczacych się. O kompetencjach, motywowaniu i strategiach. Lublin 1934, TN KUL.

Iluk J.: Jak uczyć małe dzieci języków obcych? Częstochowa 2002, Wydawnictwo Wyższej Szkoły Lingwistycznej.

Kabzińska I.: Metody nauczania języka obcego. „Życie Szkoły” 2009, nr 1.

Karbowniczek J.: Niekonwencjonalne metody alternatywne w nauczaniu języków obcych dzieci i młodzieży. „Częstochowski Biuletyn Oświatowy” 2008, nr 3(69).

Komorowska H.: Metodyka nauczania jezzyków obcych. Warszawa 2005, Fraszka Edukacyjna. 
Mazur A., Paprotna G., Pastuszka A.: Problemy nauczania języka angielskiego dzieci w młodszym wieku szkolnym. W: J. Arabski (red.): Teoria i praktyka dydaktyki języków obcych dzieci w młodszym wieku szkolnym. Katowice 2001, UŚ.

Mikulska A.: Zastosowanie alternatywnych metod nauczania na lekcjach języka obcego - metoda Community Language Learning. „Języki Obce w Szkole" 2004.

Pamuła M.: Metodyka nauczania języków obcych w kształceniu zintegrowanym. Warszawa 2003, Fraszka Edukacyjna.

Szalast-Bytys U.: Zachęcać, motywować, aktywizować i uczyć... efektywnie, czyli o metodach aktywizujacych w procesie nauczania języka obcego. W: J. Knieja, S. Piotrkowski (red.): Nauczanie jezzyka obcego a specyficzne potrzeby uczacych się. O kompetencjach, motywowaniu i strategiach. Lublin 1994, TN KUL.

Szałek M.: Jak motywować uczniów do nauki języka obcego? Motywacja w teorii i praktyce. Poznań 2004, WAGROS.

Szałek M.: Niektóre teoretyczne i praktyczne aspekty nauczania języków obcych dzieci. „Języki Obce w Szkole” 1987, nr 3.

Szpotowicz M., Szulc-Kurpaska M.: Jezzyk angielski w nauczaniu zintegrowanym. Program nauczania języka angielskiego dla klas I-III szkoty podstawowej. Warszawa 2001, PWN.

Szpotowicz M.: Lekcja języka obcego w nauczaniu wczesnoszkolnym. W: H. Komorowska (red.): Skuteczna nauka języka obcego. Struktura i przebieg zajęć jezzkowych. Warszawa 2009, CODN.

\section{Multicultural education on a foreign language lesson in lower classes. Practical solutions for teachers}

Abstract: This article concerns the introduction of multicultural education contents as a part of foreign language classes in primary schools. It presents some practical solutions which may help teachers prepare attractive lessons, get their students interested and encourage them to active participation. These suggestions will allow them to expand their multicultural awareness which, in a culturally diverse world, is the basis for fascination and tolerance towards other cultures.

Key words: multicultural education, foreign languages, primary education 